$A B C D$ Arq Bras Cir Dig Letter to the Editor 2014;27(2):160-161

\section{MESENTERIC CYST: ABDOMINAL LYMPHANGIOMA}

\author{
Cisto mesentérico: linfangioma abdominal
}

Diogo Gontijo Dos REIS ${ }^{1}$, Nícollas Nunes RABELO ${ }^{1}$, Sidnei Jose ARATAKE ${ }^{2}$

From ${ }^{1}$ Serviço de Ortopedia da Faculdade Atenas (Orthopedics Service of Paracatu Atenas School), Paracatu, MG and ${ }^{2}$ Serviço de Cirurgia Geral do Hospital São Francisco (Service of General Surgery, San Francisco Hospital), Taquaral, GO, Brazil.

\section{Correspondence:}

Nícollas Nunes Rabelo

nicollasrabelo@hotmail.com

Financial source: none

Conflicts of interest: none

Received for publication: 14/12/2012 Accepted for publication: 23/11/2013

\section{INTRODUCTION}

Mesenteric cyst is defined as a cystic lesion located between the leaflets of the mesentery from the duodenum to the rectum, being most commonly found in ileum level. Since its first description in 1507 by Benevienae until 1993 there are only about 820 cases reported in the literature ${ }^{4-6}$.

Lymphangiomas are benign tumors, probably congenital, are more common in the cervical and axillary regions. They are unusual in abdominal and pancreas location. Its incidence is estimated at around 1:100,000 and 1:20,000 admissions in adults and in children. The first excision was performed by Tillaux (quoted Chung) only in $1802^{5}$. Despite the long recognition of this disease, its origin classification and pathology remain controversial. The highest incidence is between the third and fourth decades of life, with $75 \%$ of those diagnosed after ten years with a slight female predominance. The term lymphangioma is appropriately used when there is hemodynamic isolation, or the injury is not related to the blood system ${ }^{10-13}$. Lymphangiomas are a major group of so-called vascular hamartomas, which result from a failure in the evolutionary development of the vascular system, including lymphatic and/or arteries and veins ${ }^{3}$.

These lymphatic tumors are divided in: 1) simple, with capillary lymphatic channels; 2 ) cavernous, with dilated lymphatics and the presence of capsule; and 3) macrocystic malformations, clinically termed "cystic hygroma"6. This is the most common type, and the most affected sites are head and neck. The main differential diagnosis is hemangioma, branchial cysts, lipomas and rabdmiossarcoma. Diagnosis is made by biopsy of suspicious nodules, and the main treatment is surgical excision.

\section{CASE REPORT}

Fifty-eight years man came to San Francisco Hospital in Taquaral of Goiás, Brazil, after previous medical care without diagnosis or treatment. He had a history of a large mass over a year of slow evolutionary character. He denied pain, headache, fever, diarrhea and other symptoms. Physical examination revealed good general condition, acyanotic, afebrile, hydrated, normotensive, rhythmic, symmetrical heart sounds without murmur. His abdomen had a moving mass of $10 \mathrm{~cm}$ in diameter, painless to superficial and deep palpation. Ultrasonography showed an intraperitoneal cyst apparently mesenteric (Figure 1).

With the uncertain diagnosis was conducted to computed tomography of the abdomen reviling a hyperdense mass of cystic aspect, not contrasted, measuring $9.0 \times 7.1 \mathrm{~cm}$ in its greatest transverse axis located in the hypogastrium, without being adherent to the bladder (Figure 2). Was opted to indicate exploratory laparotomy through supra-umbilical median approach. Was encountered an intraperitoneal cyst in the region of retouterine recess (Douglas), totally free and avascular (Figure 3). Histopathologic examination was a mesenteric cyst/lymphangioma. The patient was discharged without intercurrences.

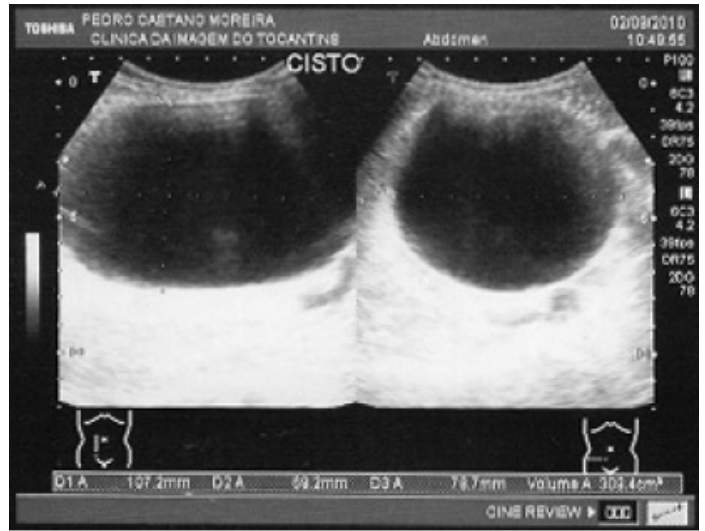

FIGURE 1 - Ultrasound image of the abdomen with intraperitoneal cyst

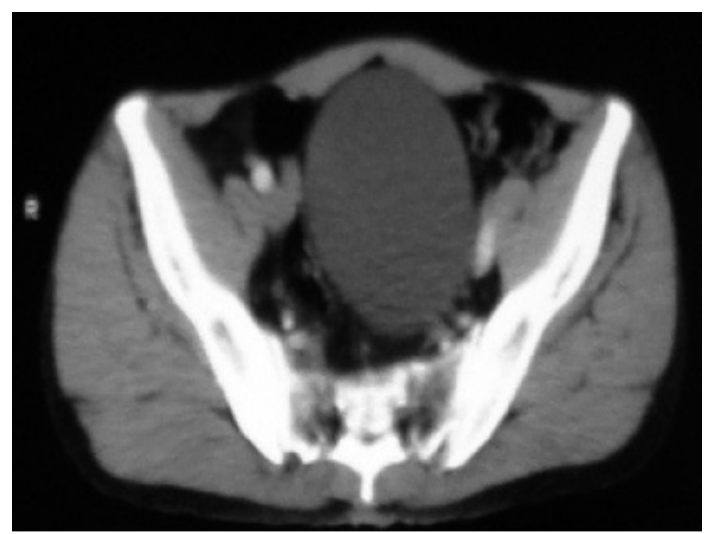

FIGURE 2 - CT scan with contrast of the abdomen showing the median cystic image

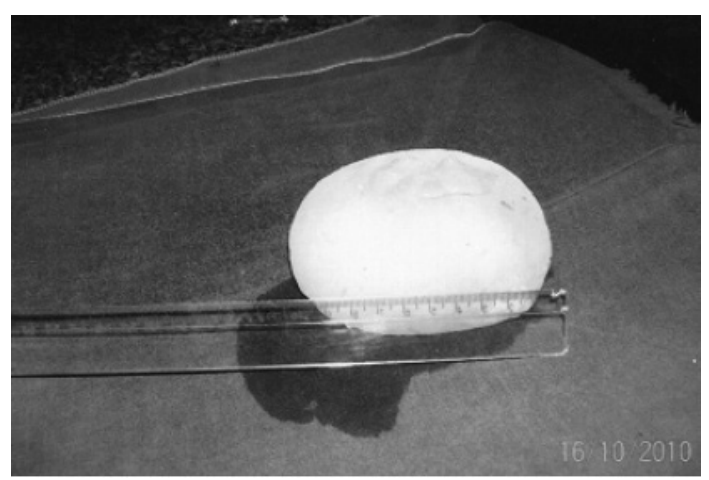

FIGURE 3 - Resected cyst (lymphangioma) 


\section{DISCUSSION}

There are no pathognomonic signs and symptoms of mesenteric cyst; However, paper presented by Santana et al. ${ }^{11}$ reporting 18 cases showed abdominal pain and mass (72\%), vomiting and constipation; one patient presented with acute abdomen pain. Palpation usually presents itself painless, smooth contour and well defined with mobility in the transverse direction and around its axis (Tillaux signal) 2-11 $^{-11}$ The increase in abdominal volume is slow, progressive and late noticed in some cases, mingling with ascites in about 18-20\%. There are few reports of malignant mesenteric cysts, usually low-grade sarcomas. Kurtz et al. reviewed 162 cases and found only $3 \%$ of malignant transformation, all in adults. Are incidental findings during laparotomy or imaging, up to $40 \%$ of cases. Acute abdomen occurs when there is rupture, infection, bleeding or twisting of the cyst, and confused with appendicitis or aortic aneurysm.

Laboratory tests little help the diagnosis. Simple X-rays of the abdomen may show calcifications; arteriography and intestinal transit may show compressive mass. However, ultrasonography, computed tomography computed and magnetic resonance imaging are the exams that provide better diagnosis.

Once diagnosed, all mesenteric cyst should be resected in order to avoid their complications ${ }^{2-11}$, recurrence, malignant transformation and possible complications (hemorrhage, torsion, obstruction, traumatic rupture and infection) ${ }^{8-12}$. Internal drainage may be an option when there is possibility of short bowel syndrome. In selected cases laparoscopic approach can be used ${ }^{13-15}$.

Santana et al. ${ }^{11}$ classified them as pathologically serous, bloodserous, chylous, with blood. In this case hydatid cist was also placed on judgment in the differential diagnosis, before the end of lymphangioma.

\section{REFERENCES}

1. Alvarez $C$ et all.Linfangioma cístico do pâncreas. Revista do Colégio Brasileiro de Cirurgiões: Vol. 27 - 6 -n.430.

2. Blss DP, Coffin CM, Bower RJ, et al.Mesenteric cyst in children. Surgery 1994; 115(5):571-7.

3. Boecha TP. et al. Linfangioma Abdominal na Crianças: Apresentação de 8 casos. Jornal de Pediatria 1996; - Vol. 72, №5.

4. Cardoso Araújo F. Landim Machado F, Perdigão B. F-Linfagioma Cístico: Uma rara apresentação de abdomen agudo: Revista do Colégio Brasileiro de Cirurgiões .Vol. 27 - no $2-137$

5. Chung MA, Brandt ML, St-Vil D et al:Mesenteric cyst in children. J Pediat Surg 1991; 26(11):1306-.

6. Coelho UCJ. Manual De Clínica Cirúrgica.São Paulo. Ed.Atheneu,2009. Vol.2.Pág.1662.

7. Liew SCC, Glenn DC, Storey DW.Mesenteric cyst: Aust.N.Z.J. Surg 1994; 64(11):741-744

8. Mackenzien DJ, Shapiro SJ, Gordon LA, Ress R. Laparoscopic excision of a mesenteric cyst. J Laparoendosc Surg. 1993; 3(3):295-9.

9. Okumu M, Salman T, Gùrlen N, Salman N.Mesenteric cyst infected with non-typhoidal salmonella infection. Pediatr Surg Int. 2004; 20(1112):883-5

10. Pereira JF, Trindade PS, Velasco AA, Salum PT. Linfangioma Orbitrario: Relato de Caso. Arq Bras Oftalmol 2010;73(1):84-87.

11. Santana B, et al. Cisto Mesenterico e Aspectos Clínicos e anatomopatologicos. Rev. Col. Bras.Cir 2010; 37(4): 260-264.

12. Shamiyeh A, Rieger R, Schrenk P, Wayand W. Role of laparoscopic surgery in treatment of mesenteric cysts. Surg Endosc. 1999;13(9):9379.

13. Tucker SM. Vascular lesions of the orbit. In: Duane's clinical ophthalmology. Philadelphia 2000: Lippincott-Raven.

14. Vara-Thorbeck C, Méndez RT, Hidalgo RH, et al. Laparoscopy resection of a giant mesenteric cystic lymphangioma.Eur J Surg 1997; 163: 395-6

15. Wootton-Gorges SL, Thomas KB, Harned RK, Wu SR, Stein-Wexler R, Strain JD. Giatt cystic abdominal masses in children. Pediatr Radiol. 2005; 35(12):1277-88
ABCD Arq Bras Cir Dig Letter to the Editor 2014;27(2):161-162

\section{INADVERTENT TATTOOING OF ADJACENT LARGE BOWEL: A CASE REPORT AND REVIEW OF LITERATURE}

Tatuagem inadvertida de intestino grosso adjacente: relato de caso e revisão da literatura

Itai GHERSIN ${ }^{1}$, Gideon SROKA ${ }^{2}$, Bassel HAJ², Dana Shaylovsky GHERSIN ${ }^{1}$ Ibrahim MATTER $^{2}$

From the ${ }^{1}$ Rappaport Faculty of Medicine, Technion, Israel Institute of Technology and 'Department of Surgery, Bnai Zion Medical Center, Haifa, Israel

Correspondence:

Financial source: none

Itai Ghersin

E-mail address:

ighersin@gmail.com

Conflicts of interest: none

Received for publication: 15/01/2013

Accepted for publication: 23/11/2013

INTRODUCTION

Marking of colonic lesions which require surgical resection prior to surgery is of extreme importance, especially since laparoscopic approach is becoming increasingly common in colonic resections. Endoscopic tattooing of lesions, using dyes such as India ink, is recommended in such cases $^{1}$, and is currently the most commonly used marking technique. This procedure was found to be both effective and safe in several studies. ${ }^{2,3}$

Several side effects and complications of India ink tattooing have been reported. Among them are localized leakages of ink into the peritoneal cavity, which were mostly asymptomatic ${ }^{3}$, and transmural injection of India ink into adjacent structures, such as small bowel ${ }^{4}$ and rectus muscle. ${ }^{5}$ However, we were not able to find any reports describing transmural injection of India ink into adjacent segments of large bowel, which prompted us to submit our case.

We present the case of a patient who underwent endoscopic tattooing of a colonic lesion prior to surgery. At laparotomy we noticed that the India ink was injected through the colon wall into an adjacent segment of large bowel, thus leading to inaccurate marking of the lesion.

\section{CASE REPORT}

A 75 year old woman, with a history of hypothyroidism and essential hypertension, underwent a screening colonoscopy for the first time in her life. It is worth noting that the patient was asymptomatic. Colonoscopy revealed two polyps which were deemed endoscopically unresectable: one at the cecum and one at $40 \mathrm{~cm}$ from the anus. Both were biopsied, and a marking with India ink was made distal to the lesion at $40 \mathrm{~cm}$ in order to easily locate it at surgery. Both biopsies showed tubulovillous adenoma with areas of high grade dysplasia.

Further workup, including complete blood count, liver enzymes, CEA levels, chest $\mathrm{x}$-ray and abdominal $\mathrm{CT}$, was normal.

It was decided to proceed to surgery. We initially attempted to perform a laparoscopic resection, but due to 